\title{
Video Article \\ Neural-Colony Forming Cell Assay: An Assay To Discriminate Bona Fide Neural Stem Cells from Neural Progenitor Cells
}

\author{
Hassan Azari ${ }^{1,2}$, Sharon A. Louis ${ }^{3}$, Sharareh Sharififar ${ }^{1}$, Vinata Vedam-Mai ${ }^{1}$, Brent A. Reynolds ${ }^{1}$ \\ ${ }^{1}$ Department of Neurosurgery, University of Florida \\ ${ }^{2}$ Department of Anatomical Sciences, Shiraz University of Medical Sciences \\ ${ }^{3}$ STEMCELL Technologies, Inc. \\ Correspondence to: Hassan Azari at Hassan.azari@neurosurgery.ufl.edu
}

URL: https://www.jove.com/video/2639

DOI: doi:10.3791/2639

Keywords: Neuroscience, Issue 49, Stem Cells, Neural Colony Forming Cell Assay, Progenitor Cells, enumeration

Date Published: $3 / 6 / 2011$

Citation: Azari, H., Louis, S.A., Sharififar, S., Vedam-Mai, V., Reynolds, B.A. Neural-Colony Forming Cell Assay: An Assay To Discriminate Bona Fide Neural Stem Cells from Neural Progenitor Cells. J. Vis. Exp. (49), e2639, doi:10.3791/2639 (2011).

\section{Abstract}

The neurosphere assay (NSA) is one of the most frequently used methods to isolate, expand and also calculate the frequency of neural stem cells (NSCs). Furthermore, this serum-free culture system has also been employed to expand stem cells and determine their frequency from a variety of tumors and normal tissues. It has been shown recently that a one-to-one relationship does not exist between neurosphere formation and NSCs. This suggests that the NSA as currently applied, overestimates the frequency of NSCs in a mixed population of neural precursor cells isolated from both the embryonic and adult mammalian brain. This video practically demonstrates a novel collagen based semi- solid assay, the neural-colony forming cell assay (N-CFCA), which has the ability to discriminate stem from progenitor cells based on their long-term proliferative potential, and thus provides a method to enumerate NSC frequency. In the N-CFCA, colonies $\geq 2 \mathrm{~mm}$ in diameter are derived from cells that meet all the functional criteria of a NSC, while colonies $<2 \mathrm{~mm}$ are derived from progenitors. The N-CFCA procedure can be used for cells prepared from different sources including primary and cultured adult or embryonic mouse CNS cells. Here we use cells prepared from passage one neurospheres generated from embryonic day 14 mice brain to perform N-CFCA. The cultures are replenished with proliferation medium every seven days for three weeks to allow the plated cells to exhibit their full proliferative potential and then the frequency of neural progenitor and bona fide neural stem cells is calculated respectively by counting the number of colonies that are $<2 \mathrm{~mm}$ and the ones that are $\geq 2 \mathrm{~mm}$ in reference to the number of cells that were initially plated.

\section{Video Link}

The video component of this article can be found at https://www.jove.com/video/2639/

\section{Protocol}

\section{Items That Need to Be Prepared Before Proceeding to Cell Plating:}

1. Appropriate volume of complete NSC medium is prepared by mixing NeuroCult NSC Basal Medium and NeuroCult NSC Proliferation Supplements at a 9:1 ratio, respectively.

2. An aliquot of NeuroCult NCFC Serum-Free Medium without Cytokines is thawed.

3. The medium is warmed up in a $37^{\circ} \mathrm{C}$ water bath.

4. Stock solutions of epidermal growth factor (EGF), basic fibroblastic growth factor (b-FGF) at the concentration of $10 \mu \mathrm{g} / \mathrm{mL}$ and heparin at $0.2 \%$ are prepared ahead.

5. Depending on the experiment size, several $35 \mathrm{~mm}$ tissue culture dishes are needed to plate the cells and one $150-200 \mathrm{~cm}$ plastic Petri dish is also needed to hold the duplicate $35 \mathrm{~mm}$ dishes and a third $35 \mathrm{~mm}$ dish for water.

\section{Cell Preparation:}

Depending on your experiment, cells can be prepared from an adult or embryonic source (primary dissociated tissue or dissociated neurospheres). Dissect tissues from adult/embryonic mouse central nervous system (CNS) or dissociate adult/embryonic-derived neurospheres as described before ${ }^{1,2}$ and then:

1. The single cell suspension is passed through a 40- $\mu \mathrm{m}$-size mesh filter so as to remove non-dissociated clumps.

2. $10 \mu \mathrm{l}$ of the cell suspension is mixed with $90 \mu \mathrm{l}$ of Trypan blue to perform a cell count. Note: Other appropriate cell dilutions can also be used. 
3. If using primary embryonic or adult derived neural cells, dilute the cell suspension to a concentration of $6.5 \times 10^{5} \mathrm{cells} / \mathrm{mL}$ in complete NSC medium. If using cells from dissociated neurospheres derived from adult or embryonic neural cells, dilute the cell suspension to a concentration of $2.2 \times 10^{5}$ cells $/ \mathrm{mL}$ in complete NSC medium.

\section{Plating Cells in Semi-solid N-CFCA Medium:}

1. The appropriate volume of the following components is mixed in order, depending on the number of replicates. Here we mix the amount needed for two replicates or duplicate dishes. For additional numbers of replicates, please refer to table 1.

- $1.7 \mathrm{~mL}$ of NeuroCult NCFC Serum-Free Medium without Cytokines

- $330 \mu \mathrm{L}$ of NeuroCult NSC Proliferation Supplements

- $6.6 \mu \mathrm{L}$ of EGF $(10 \mu \mathrm{g} / \mathrm{mL})$

- $32 \mu \mathrm{L}$ of Penicillin/Streptomycin

- $\quad 3.3 \mu \mathrm{L}$ of b-FGF $(10 \mu \mathrm{g} / \mathrm{mL})$ required only if culturing cells derived from adult neural cells

- $\quad 3.3 \mu \mathrm{L}$ of heparin $(0.2 \%)$ required only if culturing cells derived from adult neural cells.

- $25 \mu \mathrm{L}$ of cell suspension (of $2.2 \times 10^{5}$ cells $/ \mathrm{mL}$ cells from dissociated neurospheres or $6.5 \times 10^{5}$ cells $/ \mathrm{mL}$ primary cells from dissociated CNS tissue). Note: The final cell numbers plated should be about 2500 cells per $35 \mathrm{~mm}$ culture dish for neurosphere derived cells and 7500 cells per $35 \mathrm{~mm}$ culture dish for primary cells. In some cases, the final cell plating density has to be adjusted by performing a cell titration experiment. For statistical analyses, the total number of colonies detected after 21 days of culture should be within the range of at least $50-150$ colonies.

2. The medium containing the cells is mixed gently and then $1.3 \mathrm{~mL}$ of cold Collagen solution is transferred to the cell suspension and mixed well by gentle pipetting to avoid introducing any bubbles.

3. The mixed solution is dispensed to the center of each $35 \mathrm{~mm}$ culture dish $(\sim 1.5 \mathrm{~mL} / \mathrm{dish})$ and the dishes are tipped gently using a circular motion to let the mixture spread evenly over the surface of the dish. .

4. The duplicate $35 \mathrm{~mm}$ culture dishes are placed into a $100 \mathrm{~mm}$ Petri plate. The lid of new $35 \mathrm{~mm}$ dish is removed and the open dish is also placed in the same $100 \mathrm{~mm}$ Petri dish. Sterile water is added to this open $35 \mathrm{~mm}$ dish to maintain optimal humidity during the incubation period. Square bioassay plates $(245 \mathrm{~mm})$ are used when more replicate $35 \mathrm{~mm}$ dishes have been set up. Again, include 2 or 3 open $35 \mathrm{~mm}$ dishes containing sterile water.

5. The plates are transferred to an incubator set at $37^{\circ} \mathrm{C}, 5 \% \mathrm{CO} 2$ and $95 \%$ humidity. The collagen congeals by increasing temperature and gel formation will occur within approximately one hour. The cultures should not be disturbed during this time.

6. Cultured cells are incubated for 21 days (differences in colony size can be clearly distinguished after 21 days).

\section{Preparing Replenishment Medium and Feeding the Culture:}

As N-CFCA cultures are incubated for an extended period of time (21 days), cultures should be fed with the appropriate complete NeuroCult replenishment medium prepared fresh as follows:

- $4.5 \mathrm{~mL}$ of NeuroCult NSC Basal Medium is mixed with $0.5 \mathrm{~mL}$ of NeuroCult NSC Proliferation Supplements and then the growth factors is added:

- $250 \mu \mathrm{L}$ of $10 \mu \mathrm{g} / \mathrm{mL}$ EGF (to give a final concentration of $0.5 \mu \mathrm{g} / \mathrm{mL}$ EGF)

- $125 \mu \mathrm{L}$ of $10 \mu \mathrm{g} / \mathrm{mL}$ b-FGF (to give a final concentration of $0.25 \mu \mathrm{g} / \mathrm{mL}$ b-FGF) required only if culturing cells derived from adult neural cells.

- $125 \mu \mathrm{L}$ of $0.2 \%$ Heparin, required only if culturing cells derived from adult neural cells.

- $60 \mu \mathrm{L}$ of the appropriate complete NeuroCult Replenishment Medium (for embryonic or adult cells) is added into the center of each NCFC Assay dish once every 7 days during the entire NCFC Assay culture incubation ( 21 days).

\section{Scoring N-CFC Assay Derived Colonies and Calculating the Frequency of bona Fide NSCs and Neural Progenitor Cells:}

- Each $35 \mathrm{~mm}$ culture dish is placed on a gridded scoring dish with the grid size of $2.0 \mathrm{~mm} \times 2.0 \mathrm{~mm}$ and then both dishes are placed on the microscope stage.

- Using low power (2.5X - 5X) objective lens, each dish is scanned and the colonies are scored based on their sizes.

- Colonies are classified into two major categories:

1. Less than $2 \mathrm{~mm}$ diameter

2. $\geq 2 \mathrm{~mm}$ diameter

\section{Representative Results:}

As in neurosphere assay, cells plated in N-CFC assay start to proliferate and make small colonies of cells within 3 - 7 days after plating (Figure 1). In two weeks time, colonies of different sizes can be distinguished. While the majority of colonies tend to stop growing after 14 days, some colonies continue to increase in size. By day 21, colonies can be classified into one of the four categories: 1) less than $0.5 \mathrm{~mm}$ diameter, 2 ) 0.5 - $1 \mathrm{~mm}$ diameter, 3) $1-2 \mathrm{~mm}$ diameter and 4) $\geq 2 \mathrm{~mm}$ in diameter. Practically, colonies smaller than $2 \mathrm{~mm}$ diameter are referred to as progenitor derived (Figure 2) and colonies $\geq 2 \mathrm{~mm}$ in diameter are referred to as NSC derived (Figure 3). The number of colonies $\geq 2 \mathrm{~mm}$ in diameter per total cells plated, represents the frequency of the actual bona fide neural stem cells with long-term self-renewal and multi-potential capabilities. The total neurosphere forming frequency in a particular cell population after 7-8 day in a parallel NSA experiment has been estimated to be similar 
to the total colony forming frequency of the same cell population after 21 days in a N-CFCA experiment. The N-CFCA however, provides a more permissive condition so as each cell can show its full proliferative potential.

\begin{tabular}{|l|l|l|l|}
\hline Component & 2 replicates & 3 replicates & 4 replicates \\
\hline $\begin{array}{l}\text { NeuroCult NCFC Serum-Free } \\
\text { Medium without Cytokines }\end{array}$ & 1700 & 2550 & 3400 \\
\hline $\begin{array}{l}\text { NeuroCult NSC Proliferation } \\
\text { Supplements }\end{array}$ & 330 & 495 & 660 \\
\hline EGF $(10 \mu \mathrm{g} / \mathrm{mL})$ & 6.6 & 9.9 & 13.2 \\
\hline $\begin{array}{l}\text { bFGF }(10 \mu \mathrm{g} / \mathrm{mL}), \text { only for adult } \\
\text { cells }\end{array}$ & 3.3 & 4.95 & 6.6 \\
\hline $\begin{array}{l}\text { Heparin Solution }(0.2 \%), \text { only for } \\
\text { adult cells }\end{array}$ & 3.3 & 4.95 & 6.6 \\
\hline Penicillin/Streptomycin $(1: 100)$ & 32 & 48 & 64 \\
\hline $\begin{array}{l}\text { Cells at: } \\
2.2 \times 10^{5} \text { cultured cells } / \mathrm{mL} \text { OR } \\
6.5 \times 10^{5} \text { primary cells } / \mathrm{mL}\end{array}$ & 25 & 37.5 & 50 \\
\hline Collagen Solution & 1300 & 1950 & 2600 \\
\hline
\end{tabular}

Table 1. Components of complete N-CFC assay culture.

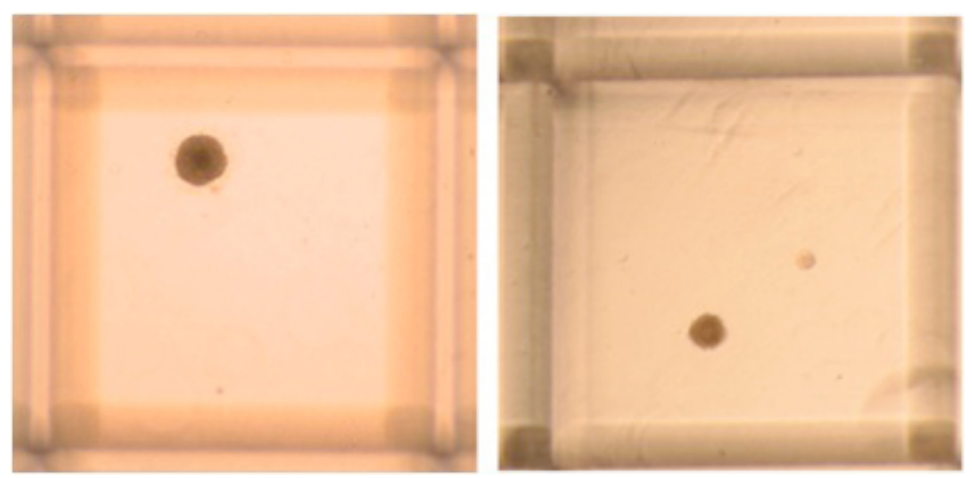

Figure 1. Representative colonies in N-CFCA culture of passage one E14 mouse NSCs 7 days after plating. The colonies might display different morphology and size. Original magnification; $4 \mathrm{x}$ 

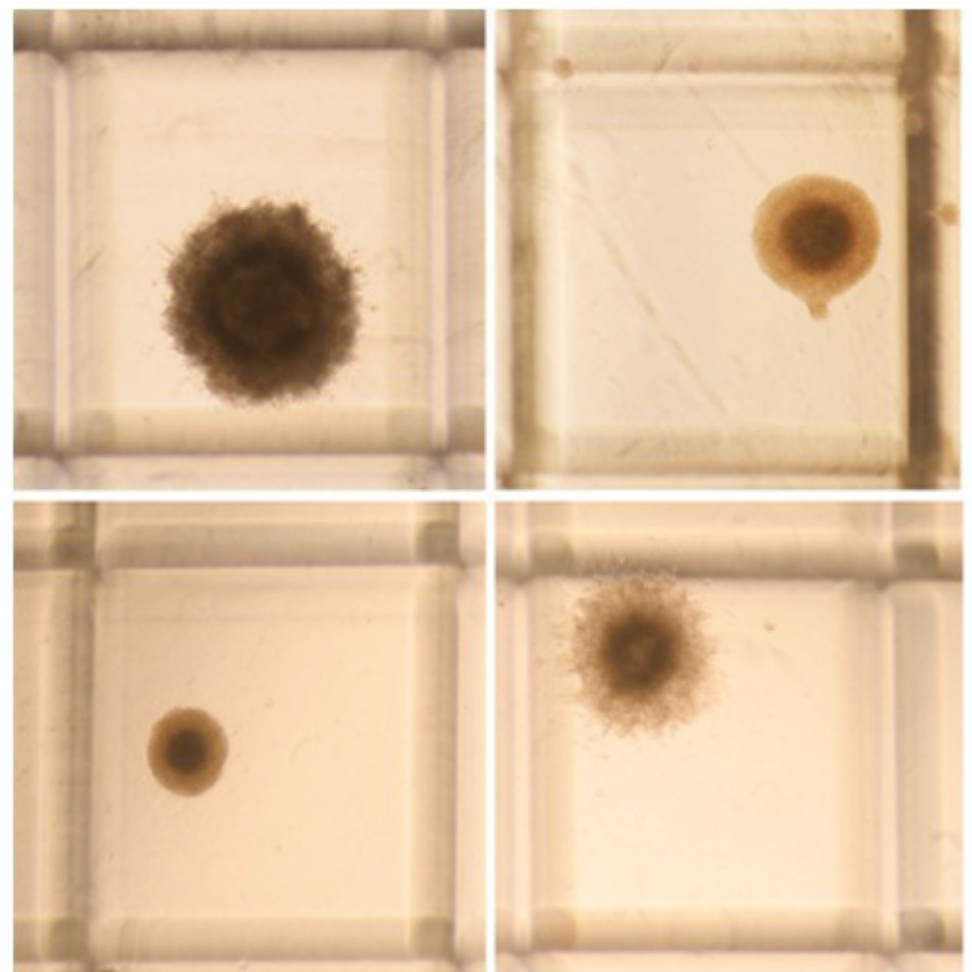

Figure 2. Representative progenitor derived colonies of different sizes in N-CFCA culture of passage one E14 mouse NSCs 21 days after plating. As shown, the colonies have different morphology but all are less $2 \mathrm{~mm}$ in size. Original magnification; $4 \mathrm{x}$

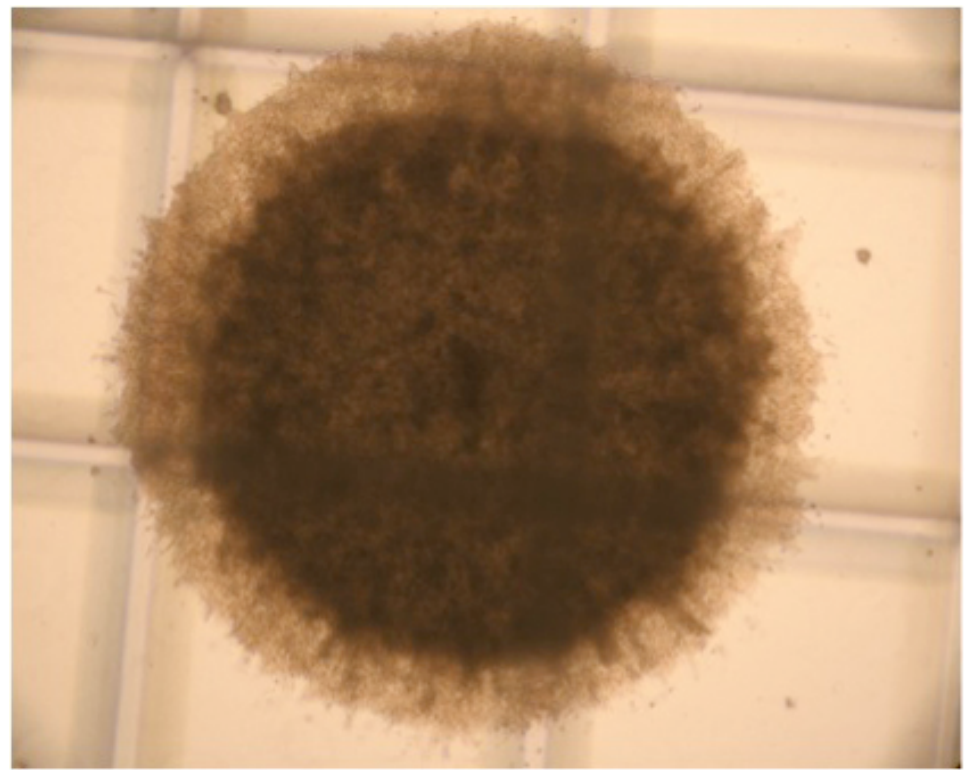

Figure 3. Representative bona fide stem cell derived colony in N-CFCA culture of passage one E14 mouse NSCs 21 days after plating. Stem cell derived colonies might display different morphology (see the video) but all are $\geq 2 \mathrm{~mm}$ in diameter. Original magnification; $4 x$

\section{Discussion}

Although neurosphere assay ${ }^{3,1,2}$ is the most common method to isolate and expand neural stem cells from a variety of sources like adult and embryonic CNS tissue, it cannot accurately measure the NSC frequency in a mixed population of neural precursor cells (stem and progenitors) as there is not a one to one relationship between the number of neurospheres and the number of bona fide stem cells ${ }^{4}$. To address this limitation, the original NSA has been adapted so as to allow the neural stem and progenitors to grow to their full proliferation capacity for three weeks ${ }^{5-7}$. Unlike the liquid NSA, in the N-CFCA the colonies are actually clonally derived, as the semi-solid collagen matrix prevents migration of the single cells plated and aggregation of colonies. For consistent results with this assay we recommend: 
1. Ensure a single cell suspension in the original cell suspension. Pass your single cell suspension through a $40-\mu \mathrm{m}$-size mesh filter so as to remove non-dissociated clumps.

2. Keep the collagen solution on ice or in the $+4^{\circ} \mathrm{C}$ fridge. Collagen is the last item to be added to the mixture of cell suspension as it congeals by increasing the temperature.

3. Do not forget to feed the culture every week. Adding the replenishment medium containing growth factor(s) once every 7 days will allow cells to continue to proliferate over the extended culture period.

4. The final cell plating density have been optimized for cells derived from either primary or cultured neural cells so that the total number of colonies detected after 21 days of culture in the NCFC-A is within the range of at least $50-200$ colonies. This range allows detection of the rare NSC derived colonies $>2 \mathrm{~mm}$ in diameter in samples while providing sufficient numbers of colonies for statistical analyses. Depending on the starting cell source, significantly fewer $(<50)$ and higher numbers of colonies $(>250)$ are sometimes obtained. Too few colonies will result in the colonies $>2 \mathrm{~mm}$ in diameter being below detection levels, while too many colonies will result in overcrowding anddepletion of growth medium components resulting in an inaccurate colony counting. Therefore cell plating density will need to be adjusted accordingly (i.e. increasing or decreasing the total number of cells plated)

\section{Disclosures}

One of the authors, Sharon A. Louis, is affiliated with StemCell Technologies Inc, a producer of some reagents used in this study.

\section{Acknowledgments}

This work was supported by funding from the Overstreet Foundation.

\section{References}

1. Azari, H., Rahaman, M., Sharififar, S., \& Reynolds, B.A. Isolation and Expansion of the Adult Mouse Neural Stem Cells Using the Neurosphere Assay. JoVE. 45.http://www.jove.com/index/Details.stp?ID=2393, doi: 10.3791/2393 (2010).

2. Azari, H., Sharififar, S., Rahaman, M., Ansari, S., \& Reynolds, B.A., Establishing Embryonic Mouse Neural Stem Cell Culture Using the Neurosphere Assay. JoVE. 47. http://www.jove.com/index/Details.stp?ID=2457, doi: 10.3791/2457 (2011).

3. Reynolds, B.A. \& Weiss, S., Generation of neurons and astrocytes from isolated cells of the adult mammalian central nervous system. Science 255 (5052), 1707-1710 (1992).

4. Reynolds, B.A. \& Rietze, R.L. Neural stem cells and neurospheres--re-evaluating the relationship. Nat Methods 2 (5), $333-336$ (2005).

5. Louis, S.A. et al. Enumeration of Neural Stem and Progenitor Cells in the Neural Colony Forming Cell Assay. Stem Cells (2008).

6. Golmohammadi, M.G.et al., Comparative analysis of the frequency and distribution of stem and progenitor cells in the adult mouse brain. Stem Cells 26 (4), 979-987 (2008).

7. Louis, S.A. \& Reynolds, B.A. Neurosphere and Neural Colony-Forming Cell Assays. in Protocols for Neural Cell Culture 10, 1-28 (2010). 